\title{
Manufacturing Industry and Corporate Social Responsibility on the Society
}

\author{
M. S. Nikhil ${ }^{1 *}$, M. Bhavani ${ }^{2}$ \\ ${ }^{1,2}$ Department of Studies in Commerce, Pooja Bhagavat Memorial Mahajana Education Centre, Mysuru, India \\ *Corresponding author: nikhilms0202@gmail.com
}

\begin{abstract}
This research provides the overview of the major findings that was found out during the analyses of the collected and suggestions drawn using the analyzed data. The present study deals with the impact of Corporate Social Responsibility activities on beneficiaries. Corporate Social Responsibility is a boon to the growing market. The Corporate Social Responsibility strategy has made the companies contribute to the society and economic performance of the country. Corporate Social Responsibility is the latest marketing strategy and a mandatory activity adopted by the companies to create a competitive advantage and for the economic development. The researcher studied various Corporate Social Responsibility activities initiated by manufacturing sectors and concentrated on the impact those Corporate Social Responsibility activities made on the beneficiaries. The study was made on the primary data collected from the beneficiaries of Corporate Social Responsibility activity which was initiated by JK Tyres Ltd. Mysuru. As per the data collected, JK Tyres Ltd Mysuru, have met the required norms under section 135 of the Companies Act of 2013 by carrying out the various Corporate Social Responsibility activities. JK Tyres Ltd. Mysuru have adopted 5 Villages namely Mydanahalli, Buchahalli, Mudalakoppalu, Halebeedu \& Devarahalli in BilikereHobli, Hunasur Taluk, Mysuru District. JK Tyres Ltd Mysuru adopted 3 Govt. schools namely Govt. Primary school, Mydanahalli, Govt. Primary School Buchahalli \& Govt. High School, Hosahalli. In Mysuru disctrict Hunsur Taluk JK Tyres Ltd have helped farmers by providing them with 5000 mango tree samplings, Vermi compost unit of 15 numbers, rain water harvesting units of 3 numbers, Trench cum bunding for 253.4 hectares, 21 farm ponds, 4 tanks have been de silted and 3 bore well units have been recharged.
\end{abstract}

Keywords: Beneficiaries, Corporate, JK tyres.

\section{Introduction}

Corporate Social Responsibility is to influence the society in a positive way through its regular business activities.

In most of the developing countries, Corporate Social Responsibility and philanthropy are interrelated due to their cultural traditions. Asian Countries do follow ethical practices and carry out philanthropic activities related to corporate social responsibility. The developing countries have to practice the international CSR standards, policies and principles. They are finding it difficult to practice due to the cultural differences.

\section{Corporate Social Responsibility in India}

The history of Corporate Social Responsibility in India dates back to 18th century which has been highlighted in Kautilya's Arthasastra. During the initial days of Corporate Social Responsibility practices, the two major themes in India focused on philanthropic activities and community development. In India philanthropy has been a part of business activity as well as ethical business practices. During the mid-twentieth century, Western Business Models and Practices were adopted by large companies in India. In 1980s, Corporate Social Responsibility in India started to show notable changes from conventional philanthropic activities to stakeholder and multi-stakeholder approach. Corporate Social Responsibility has been accepted as an essential part of business strategy in major industries in India.

Table 1

Table showing the percentage of CSR spending

\begin{tabular}{|l|l|}
\hline $\begin{array}{c}\text { Profit after Tax of the company } \\
\text { in the previous year }\end{array}$ & $\begin{array}{c}\text { Range of budgetary allocation for } \\
\text { CSR and sustainability activities }\end{array}$ \\
\hline Less than INR 100 crore & $3 \%-5 \%$ \\
\hline INR 100 crore to INR 500 crore & $2 \%-3 \%$ \\
\hline INR 500 Crore and above & $1 \%-2 \%$ \\
\hline
\end{tabular}

Source: The revised guidelines by DPE, with effect from 1 April 2013

The table 1 shows the percentage of budget allocated for CSR based on the profit after Tax of the company by the department of public enterprises (DPE). The companies with net profit of less than Rs. 100 crore, Rs. 100 to Rs. 500 crore and Rs. 500 \& above crores have to spend 3-5\%, 2-3\% and 1-2\% of their net profit on Corporate Social Responsibility respectively. Though Corporate Social Responsibility emerged focusing as an economic interest, over the time it expanded its interest on both economic and social aspects. Bajpai (2001) stated that an ideal Corporate Social Responsibility comprises of both ethical and philosophical aspects. In India, there exists an extensive gap between sections of people in terms of income and standards as well as socio- economic status. Companies also report the CSR accounting in their websites and it is transparent to all stakeholders. CSR initiatives of a company have also been incorporated in their annual reports.

An attempt is made to study the formation of CSR activities and the impact it will create on the lives of beneficiaries. The objective of the study is to test the impact on the social life of the beneficiaries. Scope is limited to only one manufacturing concern i.e., J K Tyres limited Mysore. Evaluation is done 
based on the secondary data obtained through annual report of J K Tyres limited and articles of the other research scholars. Primary data are collected through questionnaires and schedules by visiting beneficiaries of the CSR activities performed by JK Tyres.

\section{Statement of the Problem}

After CSR became compulsory in the companies act of 2013 it became a marketing and branding tool as well for the companies. However, many of the companies do it only for the sake of legality and not for the sake of responsibility. In many of the literature reviewed companies failed even in creating the awareness about their CSR activities. Other companies have poor or low level of implementation of these activities. When it comes to manufacturing concerns the embark on the implementation of CSR activities is remarkable. The reason is the sense of responsibility towards society or any other thing but as a matter of fact manufacturing concerns are the ones who are liable for the damage of the environment as their contribution towards that cause is higher compared to other type of industries also there is very limited data available about the impact of CSR activities on the life of the beneficiaries. Hence, this study deals in measuring the effective implementation of CSR activities of a manufacturing concern and its impact on the lives of the beneficiaries in and around Mysuru.

\section{Scope of the Study}

Scope of the study consists of Corporate Social Responsibility activities adopted by the various manufacturing concerns namely, CEAT Tyres, Apollo Tyres and TVS tyres. The scope of study extends to know the impact of CSR activity initiated by Jk Tyre Ltd Mysuru, a manufacturing concern on sanitation and its implementation in the villages Sabbanahalli, DMG halli, Gerasanahalli, Mydanahalli, Doddatti Hundi and Haalebeedu.

\section{Objectives of the Study}

The objectives of the study are:

- To gain the Conceptual Knowledge on Corporate Social Responsibility.

- To study the initiatives of CSR activities by various manufacturing concerns.

- To measure the impact of CSR activities initiated by JK Tyres Ltd Mysuru on the beneficiaries.

- To provide suggestions based upon the analysis on the data.

\section{Methodology}

The study is of descriptive nature. The present study includes the primary data collected by the beneficiaries of CSR activities initiated by JK Tyres Ltd. Mysuru by using the tool schedule under interview method. The population of the study is the beneficiaries of CSR activities initiated by JK Tyres Ltd.
Mysore. About 90 samples were considered for the study to collect primary data.

Secondary sources of data were collected from similar research articles in the journals, websites and from the annual report of the various manufacturing concerns to know the CSR activities adopted by CEAT tyres, Apollo tyres and TVS tyres.

Table 2

Corporate Social Responsibility activities of TVS Tyres

\begin{tabular}{|c|l|l|}
\hline S. No. & CSR Project & Sector in which the project is covered \\
\hline 1. & $\begin{array}{l}\text { Strengthening } \\
\text { Village Level } \\
\text { Organization }\end{array}$ & Children and Women Development \\
\hline 2. & $\begin{array}{l}\text { Intellectual } \\
\text { Development }\end{array}$ & $\begin{array}{l}\text { Education Enhancement for School and } \\
\text { Palwadi Children, Tamil Nadu }\end{array}$ \\
\hline 3. & Health & $\begin{array}{l}\text { Anemia Management and Preventive } \\
\text { Health Care, Tamil Nadu }\end{array}$ \\
\hline 4. & $\begin{array}{l}\text { Livelihood } \\
\text { Enhancement }\end{array}$ & $\begin{array}{l}\text { Entrepreneurship Development for } \\
\text { women and Youth, Tamil Nadu }\end{array}$ \\
\hline 5. & $\begin{array}{l}\text { Environmental } \\
\text { Development }\end{array}$ & $\begin{array}{l}\text { Water and Sanitation and Rural } \\
\text { Development, Tamil Nadu }\end{array}$ \\
\hline 6. & $\begin{array}{l}\text { Livelihood } \\
\text { Enhancement }\end{array}$ & Health and Nutrition, New Delhi \\
\hline 7. & $\begin{array}{l}\text { Intellectual } \\
\text { Development }\end{array}$ & $\begin{array}{l}\text { Education and Employment, } \\
\text { Tamil Nadu }\end{array}$ \\
\hline 8. & $\begin{array}{l}\text { Protection of } \\
\text { National Heritage }\end{array}$ & Art, Culture and Sports, Tamil Nadu \\
\hline
\end{tabular}

In addition to the above mentioned projects TVS tyres have adopted various other projects as well.

\section{Organization Profile - JK Tyres and Industry Ltd.}

JK industry was started by Late Lala Juggilal Singhani who had a board vision and was inspired by Swadeshi movement of Mahatma Gandhi. JK organization was started by in 19th century. Further industrial diversification was carried by Lala Kamalapal's 3 sons Sir Padmapat, Lala Kailsashpat and Lakshmipat.

JK organization is one of the topmost tyre industries which have led to the economic and social growth of India. It is also creating job opportunities to lot of people and also manufactures high quality of products. It also came out with new technology to carry on its manufacturing process and has also taken industrial ventures in several countries.

It is an association of industries and commercial and charitable trust. Nearly 50000 employees are engaged in manufacturing of variety of products. Trust is involved in promoting industrial, technical, educational, religious views, better living and various recreational facilities, Hence JK industry is contributing to the human advancement. 
Table 3

Table showing the background of the company

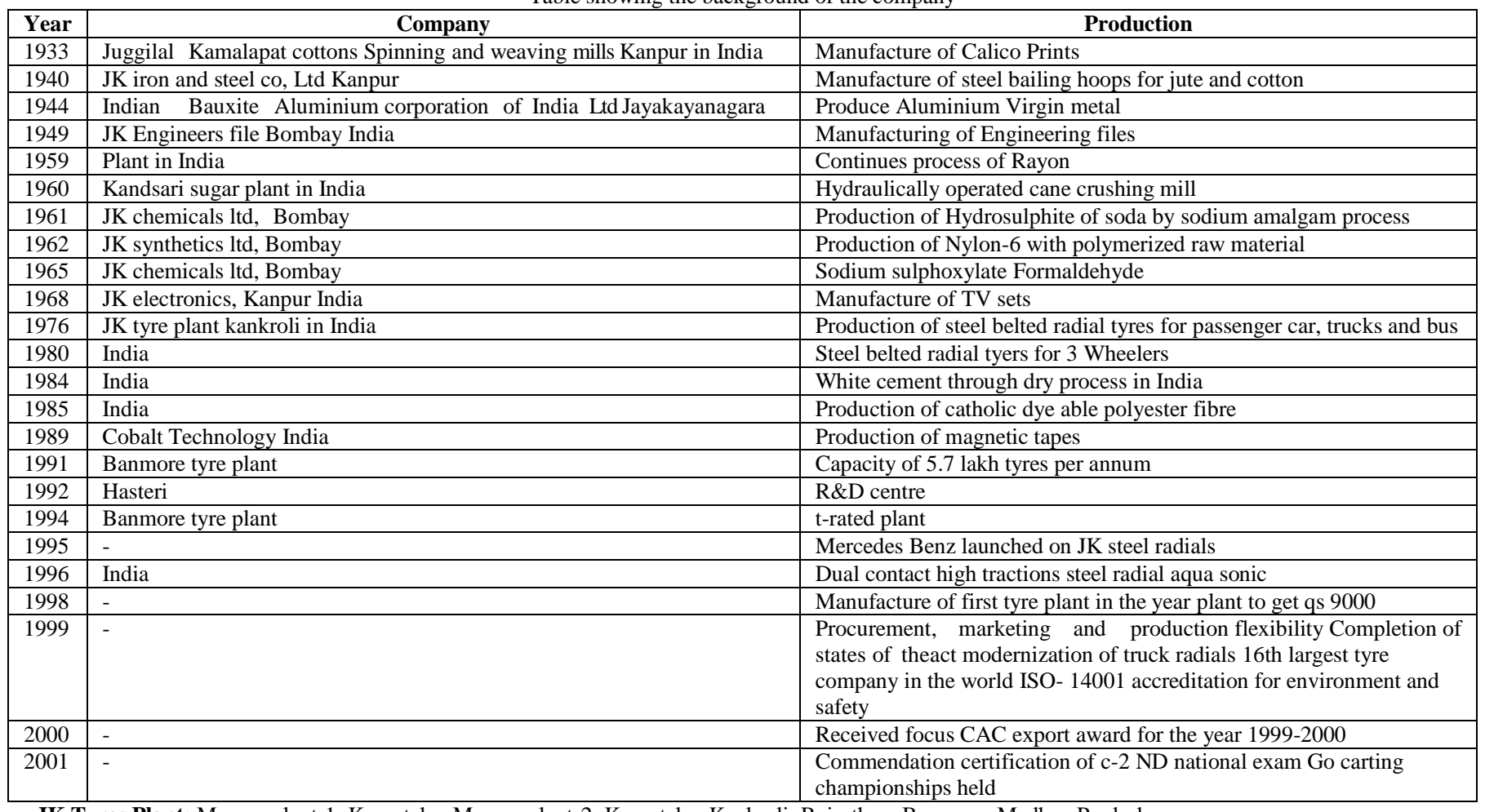

JK Tyres Plant: Mysore plant-1: Karnataka, Mysore plant-2: Karnataka, Kankroli: Rajasthan, Banmore: Madhya Pradesh

\section{A. Promoters}

Table 4

Table showing the details of promoters of JK Tyres

\begin{tabular}{|c|l|l|}
\hline S. No. & Name of the promoters & \multicolumn{1}{c|}{ Designation } \\
\hline 1 & Dr. Ragupati singhania & Chairman and Managing director \\
\hline 2 & Arun K. Bajoria & $\begin{array}{l}\text { Director and president international } \\
\text { operations }\end{array}$ \\
\hline 3 & Vivek kamara & President- India \\
\hline 4 & VK Misra & Technical Director \\
\hline 5 & AK Kinra & Finance director \\
\hline 6 & Vikram Malhotra & Marketing Director \\
\hline 7 & Dr. R Mukhopadhyay & Director( R\&D) \\
\hline 8 & AK Makkar & Manufacturing Director \\
\hline 9 & Anshuman Singhania & Whole time Director \\
\hline 10 & Sanjiv saxena & VP Corporate accounts \\
\hline 11 & Ashish pandey & VP- Materials \\
\hline
\end{tabular}

Table 5

Table showing the details of exports by JK Tyres

\begin{tabular}{|l|l|l|}
\hline Central and North America & South America & Asia-pacific \\
\hline U.S.A & Brazil & Australia \\
\hline Canada & Chile & Mauritius \\
\hline Ecuador & & Vietnam \\
\hline Guatemala & & Philippines \\
\hline Mexico & & China \\
\hline Panama & & Malaysia \\
\hline Jamaica & & \\
\hline Honduras & & \\
\hline
\end{tabular}

\section{B. Quality profile}

- The people of JK tyres have an organization committee to quality in everything they do.

- They continuously anticipate and understand customer convert these into performance standards for their product and service and to meet the standard every time.

\section{Area of Operation}

A JK tyre has acquired its brand name whole market in the world. It has created brand name to India as JK tyres and Vikrant tyres hence it acquires no 1 position in tyres market $30 \%$ of tyres are exported to 60 continents.

A JK tyre has its companies at International levels which includes 68 countries and 8 continents. The company has technical team supporters in U.S Europe, South America and Middle east and also it has strong distribution network for its products.

Various companies to which company exports its products include U.S.A. U.K. New Zeeland Hong Kong and Host of Middle east, African and Asian countries.

\section{Analysis and Interpretation}

This study has an objective to measure the impact of CSR activities initiated by various companies on beneficiaries. In order to achieve the above mentioned objective, JK Tyres Ltd Mysuru was considered for this study. JK Tyres Ltd Mysuru had initiated various activities under Corporate Social Responsibility. Those activities are:

1) Adoption of Villages

Under CSR initiative of JK Tyre \& Industries Ltd., Vikrant Tyre Plant, Mysuru, JK Tyres Ltd Mysuru have adopted 5 Villages namely Mydanahalli, Buchahalli, Mudalakoppalu, Halebeedu \& Devarahalli in BilikereHobli, Hunasur Taluk, 
Mysuru Dist. JK Tyres Ltd Mysuru have focused on comprehensive development of these villages, mainly in the areas of Health, Education, Environment Sustainability, Sanitation, Agriculture improvement, Water Management, etc.

2) Adoption of Govt. Schools

Under CSR initiative, JK Tyres Ltd Mysuru adopted 3 Govt. schools (i.e., Govt. Primary school, Myduanahalli, Govt. Primary School Buchahalli\& Govt. High School, Hosahalli) \&JK Tyres Ltd Mysuru have provided needy Benches, Racks, Paining \& Artistic work, Play Ground development, library facility \& Greenery maintenance, etc.

3) Livelihood enhancement \& Water management project

"To attain overall development of selected villages of Hunasur Taluk (Mysuru District) by achieving sustainable development in agricultural, water resources, animal husbandry, employment generation, and social development including educational improvement."

- Mango Tree Plantation -5000 Nos

- Vermi-compost Units- 15 Nos

- Bore wellrecharge Units - 3 Nos

- Tank De-siltation- 4 Nos

- Trench cum bunding- 253.4 Hectors

- Rain Water Harvesting Units - 03 Nos

- Farm Ponds - 21 Nos

4) Adult literacy project in central prison, Mysuru and remote villages

JK organization has always believed in the importance of learning, appreciating the fact that if adults are literate, the entire family will benefit and it will lead to growth of the whole community, the village and the country. JK Tyres Ltd., Mysuru have started Adult Literacy Program in2005-06 with the intention to convert illiterates into literates for better India looking at our country's illiteracy rate. So far JK Tyres Ltd Mysuru have made 22,574 people literate in remote villages of Mysuru District and Central Prison Mysore.

5) Children career counselling program

Since FY 2008-09, JK Tyres Ltd., Mysuru have been conducting the 'Children Career Counselling Programme' for employees' Children of our company and for the rural students who are studying in SSLC \& PUC. Total 5171 students got benefitted in this project.

Objective of this program was to" Impart Study Skills \& to bring the Rural Students to the main stream of Competitive Academic Education".

\section{6) Adoption of ITIs \& JK New ITI Building at Madduru}

JK Tyres Ltd. Mysuru have adopted two Govt. ITI Colleges i.e. in Maddur\& Mysore (Under PPP model) in the year of 2009-10. JK Tyres Ltd Mysuru have been conducting remedial classes for students like; Personality development, Computer knowledge \& Spoken English every year \& also with Combined efforts of JK management \& ITI Govt. Staff, JK Tyres Ltd. Mysuru have come up with a new building for ITI College at Madduru.
7) Free general medical check-up camp

Since FY 2005-06, JK Tyres Ltd. Mysuru have been conducting the 'Free General Medical Check-up Camps' in remote villages. So for 5290 beneficiaries from Poor Communities of the society got benefited by 23 such camps conducted by us in nearby villages and surrounding industrial areas.

\section{8) Voluntary blood donation camp}

Every year, JK Tyres Ltd Mysuru have been organizing Voluntary Blood Donation Camp, to commemorate the Birth Anniversary of our Beloved Chairman Late Shri Hari Shankar Singhaniaji since 2014. Till now: On 20th June of every year about 3700 people have donated blood for this cause.

9) HIV/AIDS awareness program

Since FY 2008-09, JK Tyres Ltd Mysuru have been conducting HIV-AIDS awareness program every year in schools, Colleges \& remote villages. So for 12958 beneficiaries (Community people and Students) got benefited in these programs.

\section{0) Road safety awareness program}

JK Tyres Ltd Mysuru have been conducting Road Safety awareness program in every year in schools, Colleges \& remote villages. So for 6698 beneficiaries (Community people \& Students) got benefited in these programs.

\section{1) Sanitation project under Swatch Bharat Mission}

Under CSR Initiative JK Tyres Ltd Mysuru have constructed 652 Household Toilets under "Sanitation Project" under Swatch Bharat Abhiyan at 10 Villages (Hunasur Tq, Mysuru Dist..,) in collaboration with MYKAPS (NGO) \& Zilla Panchayat, Mysuru. (100\% Elimination of open defecation in 10 villages). 12) Public road maintenance under Swatch Bharat Abhiyan

JK Tyres Ltd Mysuru have adopted $1.5 \mathrm{~km}$ public road under swatch Bharat mission namely Shri Lakshmipat Singhania Road.

\section{3) Environment sustainability}

Since 2002, every Year, JK Tyres Ltd Mysuru have been initiating samplings plantation and more than 2000 samplings have been planted year on year in remote Villages \& also public places and JK Tyres Ltd Mysuru have maintained 5-acre Green Belt area (Near TRP-II) under Swatch Bharat Abhiyan.

14) Infrastructure support to Orphanage and Hospitals

JK Tyres Ltd Mysuru are supporting "ManasaKaruna Trust" (NGO), Mysuru for the "Medical Treatment \& Medicinal Expenses "of their 25speciallyabled Women Inmates.

\section{5) Thavarekere Rejuvenation program}

Thavarekere is located in the foot hills of Chamundi Betta in the outskirts of Mysore City. The tank lies in Thavarekatte village which is one of the villages covered by Chamundi Betta Grama Panchayat in Mysore Taluk. Since there are many floJKTyres Ltd, Mysururs in the tank namely; ThavareHoo (Lotus), the tank is named as Thavarekere. The tank is situated in survey no. 4 with a total extent of 12.5 Acres. Total around 1650 people (Population) will be benefited near of 5 Villages by Chamundibetta GP, Mysuru.

Rejuvenating a tank namely "THAVAREKERE" in Mysore 
City limits, under the vision "Water Positive 2020".

On 19th Sept. 2018, under CSR initiative of VTP team have inaugurated/initiated of the "Thavarekere Rejuvenation Program", in Mysore City limits, under the vision of Mysore namely "Water Positive 2020". "Desilting and strengthening of tank including repair and renovation of waste JK Tyres Ltd Mysuruir", in association with District Industrial Centre (DIC) and MYrada KAvery Pradeshika Samsthe (Project facilitating agency).

\section{6) Livestock Development - Capacity Building}

Cattle development: provision of breed improvement and preventive health services through TTCs along with fodder demonstrations and capacity building of farmers for improved livestock rearing.

CSR - Tripartite agreement signed by NABARD, JK Tyre \& Industries Ltd. and BISLD- South Region, on 27th August 2018. additional grant support of Rs. 8,90 Lakhs to be extended by JKTIL. Is approved for the Capacity Building phase of the project FY 2018-19. JK Tyres Ltd. Mysuru have initiated for 2 Gram Panchayat.

Among the above mentioned activities Sanitation Programme under Swatch Bharath mission was selected to study the impact on beneficiaries. About 90 samples were collected using convenient sampling technique under interview method using the tool schedule. The respondents were the beneficiaries of sanitary program and demographic data of the beneficiaries was obtained from the Non-Governmental Organization called MYKAPS who were part of the program in assisting JK Tyres Ltd. Mysuru for successful completion of the programme.

It is important to collect the primary data from the respondents in order to know the impact of the scheme. The obtained data were coded and then analyzed by using simple statistical tools like frequency and simple percentage.

Table 6

Village wise classification of respondents

\begin{tabular}{|c|c|c|}
\hline Village & Frequency & Percentage \\
\hline Dodatti Hundi & 5 & 6 \\
\hline Sabbanahally & 16 & 18 \\
\hline DMG Halli & 9 & 10 \\
\hline Mydanahalli & 14 & 16 \\
\hline Haalebeedu & 19 & 21 \\
\hline Gerasanahalli & 27 & 30 \\
\hline Total & 90 & 100 \\
\hline
\end{tabular}

Source: Primary

The table 6, shows the village wise classification of the beneficiaries who was benefitted from the Sanitation program of the JK Tyres Ltd Mysuru. Every beneficiary of this program was provided a financial help of Rs. 4000 from JK Tyres Ltd. Mysore for the construction of toilet in their house. Among those 90 samples were collected and about 6 per cent of the respondents belonged to Doddatti Hundi, 18 per cent of the respondents belonged to Sabbanahally, about 10 percent of respondents belonged to DMG Halli, about 16 percent of the respondents belonged to Mydanahalli, about 21 percent of the respondents belonged to Halebeedu and about 30 percent of the respondents belonged to Gerasanahalli.

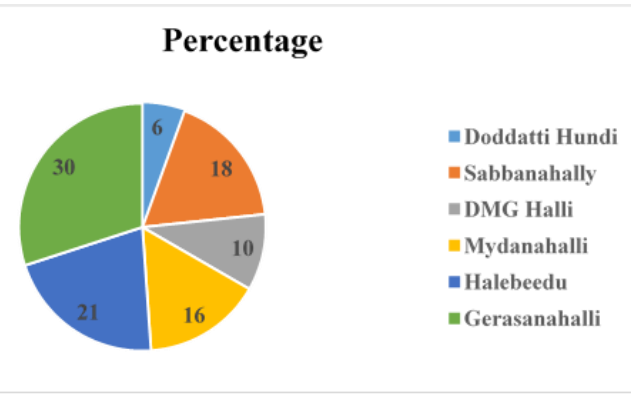

Fig. 1. Chart showing village wise classification of respondents

Table 7

Gender wise classification of respondents

\begin{tabular}{|l|l|l|}
\hline Gender & Frequency & Percentage \\
\hline Male & 46 & 51 \\
\hline Female & 44 & 49 \\
\hline Total & $\mathbf{9 0}$ & $\mathbf{1 0 0}$ \\
\hline
\end{tabular}

Source: Primary

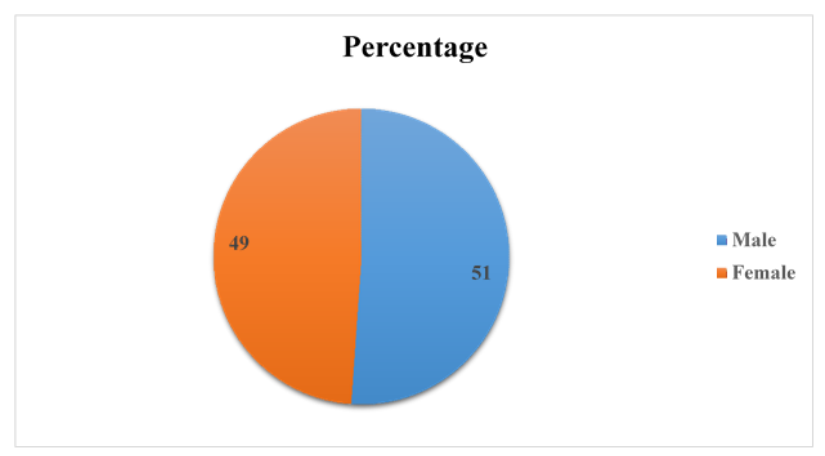

Fig. 2. Chart showing gender wise classification of respondents

The table 7, shows the gender wise classification of the beneficiaries. Among the selected 90 respondents $51 \%$ were male and $49 \%$ were female in order to know the impact of CSR activity on them. During the interview the researcher has interacted only with the head of the family.

Table 8

Respondents response on open defecation practice in the village

\begin{tabular}{|l|l|l|}
\hline Response & Frequency & Percentage \\
\hline Yes & 5 & 6 \\
\hline No & 85 & 94 \\
\hline Total & $\mathbf{8 9}$ & $\mathbf{1 0 0}$ \\
\hline
\end{tabular}

The table 8, shows the response of beneficiaries of CSR activity of JK Tyres Ltd Mysore, on the open defecation practice in their village. Out of 89 only 6 per cent of the respondents have agreed that there is still open defecation in practice. However, 94 per cent of the respondents have not agreed the practice of open defecation in the village. 


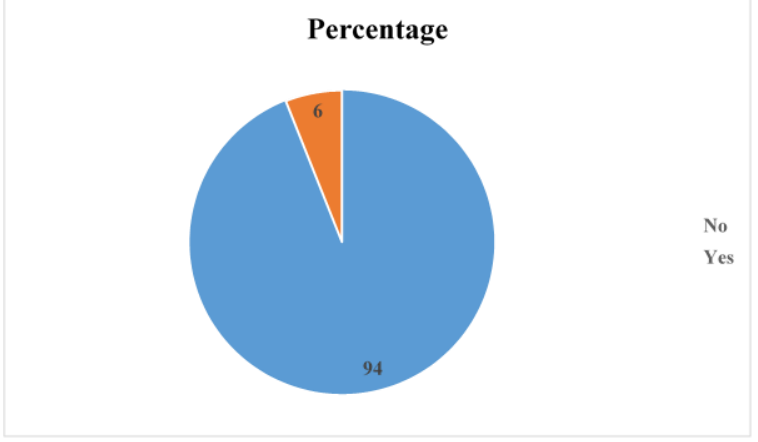

Fig. 3. Chart showing respondents response on open defecation practice in the village

Table 9

Respondents response on direct water facility in the toilet

\begin{tabular}{|l|l|l|}
\hline Response & Frequency & Percentage \\
\hline Yes & 56 & 63 \\
\hline No & 34 & 37 \\
\hline Total & $\mathbf{8 9}$ & $\mathbf{1 0 0}$ \\
\hline
\end{tabular}

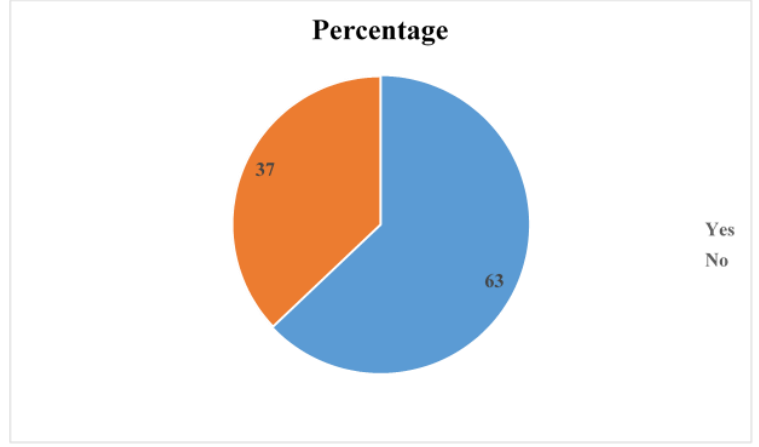

Fig. 4. Chart showing respondents response on direct water facility in the toilet

The table 9 , shows the response of beneficiaries regarding the direct water facilities in their toilets and about 63 per cent of the respondents have agreed that there is direct water facility in their toilet. However, 37 per cent of the respondents have agreed that there is no direct water facility in their toilet. They carry the water from far places to their toilet.

Table 10

Sharing of toilet with other families

\begin{tabular}{|l|l|l|}
\hline Response & Frequency & Percentage \\
\hline Yes & 3 & 3 \\
\hline No & 86 & 97 \\
\hline Total & $\mathbf{8 9}$ & $\mathbf{1 0 0}$ \\
\hline
\end{tabular}

The table 10 shows the beneficiaries response on sharing of their toilet with other families. 97 percent of the respondents have responded that they are not sharing their toilet with other families. Only 3 percent of the respondents have opined that they share their toilet with other families. The reasons were, the family which are not having the toilet facility, where there are more number of family members in other families, if there is no proper water facility with the other families, they share their toilet with those families.

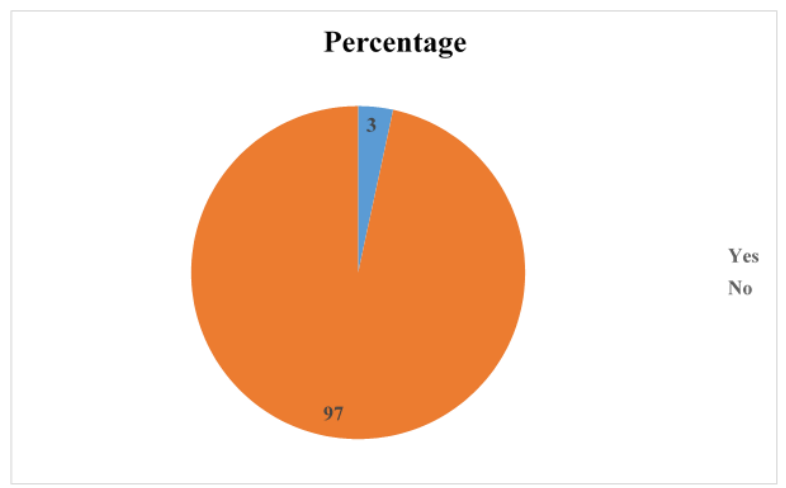

Fig. 5. Chart showing sharing of toilet with other families

Table 11

Response of respondents on location of toilet

\begin{tabular}{|l|l|l|}
\hline Response & Frequency & Percentage \\
\hline Inside & 9 & 10 \\
\hline Backyard & 79 & 89 \\
\hline Far & 1 & 1 \\
\hline Total & $\mathbf{8 9}$ & $\mathbf{1 0 0}$ \\
\hline
\end{tabular}

Source: Primary

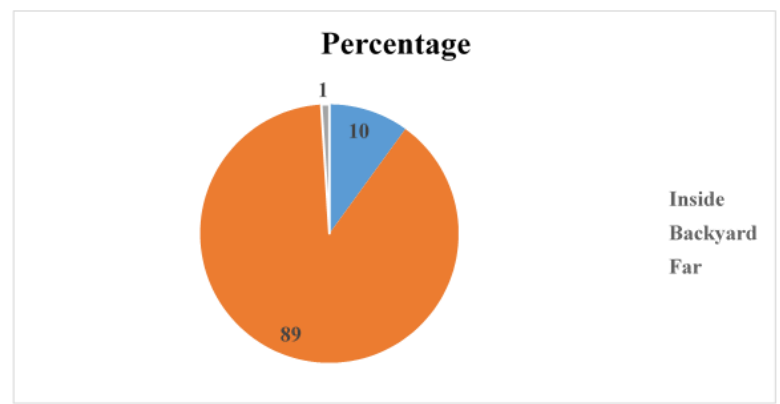

Fig. 6. Response of respondents on location of toilet

The table 11, shows the location of the toilet in the house of respondents. About 89 per cent of respondents have constructed their toilet in the backyard of their house due to ample space available and lack of space inside the house. About 1 per cent of the respondents have constructed toilet 100 meters far from the house. However, 10 per cent of the respondents have constructed their toilet inside the house.

Table 12

Response of respondents on outlet used for toilet

\begin{tabular}{|l|l|l|}
\hline Response & Frequency & Percentage \\
\hline Open Pit & 0 & 0 \\
\hline Septic Tank & 89 & 100 \\
\hline Others & 0 & 0 \\
\hline Total & $\mathbf{8 9}$ & $\mathbf{1 0 0}$ \\
\hline
\end{tabular}

The table 12, shows that all the toilets which were constructed are using septic tank as their outlet for the toilet. 


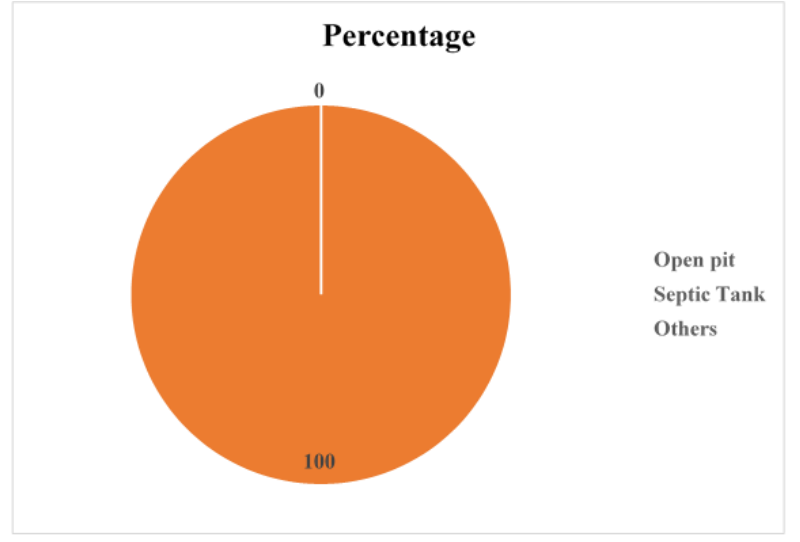

Fig. 7. Response of respondents on outlet used for toilet

Table 13

Expenses incurred by the respondents for the construction of toilet

\begin{tabular}{|l|l|l|}
\hline Expense (in Rs.) & Frequency & Percentage \\
\hline No expenses & 12 & 13 \\
\hline Less than 10000 & 26 & 29 \\
\hline $10001-20000$ & 46 & 51 \\
\hline $20001-30000$ & 5 & 6 \\
\hline Total & $\mathbf{8 9}$ & $\mathbf{1 0 0}$ \\
\hline
\end{tabular}

Source: Primary

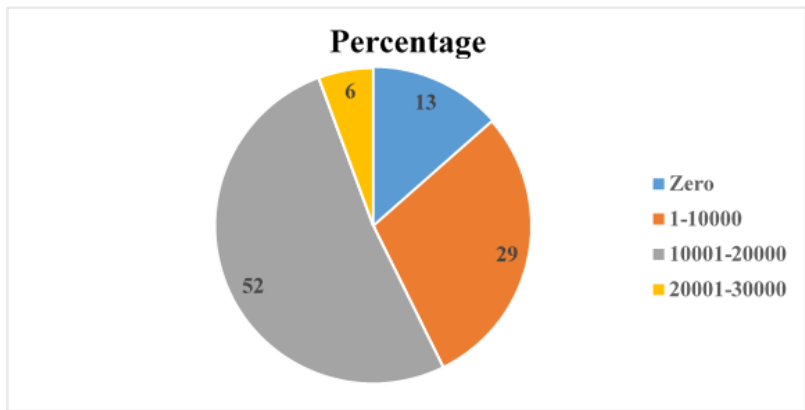

Fig. 8. Chart showing the expenses incurred by the respondents for the construction of toilet

The table 13, shows the cost incurred by the beneficiaries for the construction of toilet over and above the finance received by the Jk Tyres Ltd Mysuru and Taluk Panchayat. 13 percent of the respondents have not spent any extra money for the construction of the toilet. About 29 percent of the beneficiaries have spent less than Rs. 10000, for the construction of the toilet. About 51 per cent of the beneficiaries have spent Rs. 10000 to Rs. 20000. About 6 per cent of the beneficiaries have spent Rs. 20001 to 30000 over and above the financial support given by Jk tyres Ltd. Mysuru and Taluk Panchayat.

Table 14

Annual cost of maintenance incurred for the toilet

\begin{tabular}{|l|l|l|}
\hline Expense (in Rs) & Frequency & Percentage \\
\hline Less than 2000 & 54 & 61 \\
\hline $2001-4000$ & 26 & 29 \\
\hline $4001-6000$ & 7 & 8 \\
\hline $6001-8000$ & 2 & 2 \\
\hline Total & $\mathbf{8 9}$ & $\mathbf{1 0 0}$ \\
\hline
\end{tabular}

Source: Primary

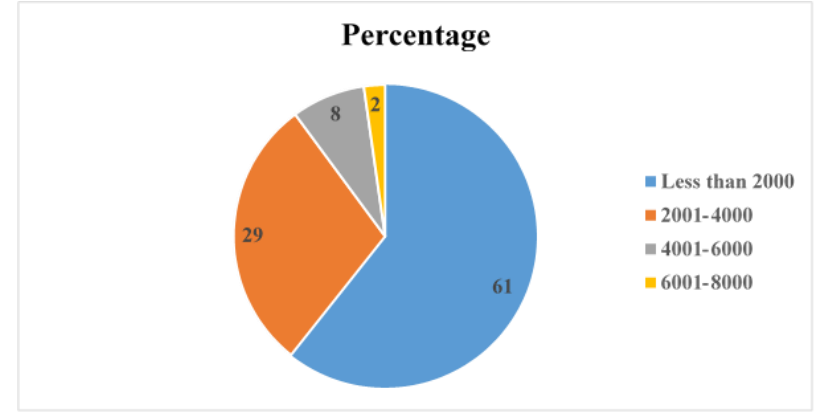

Fig. 9. Annual cost of maintenance incurred for the toilet

The table 14, shows that the annual cost of maintenance of toilet incurred by the beneficiaries. About 61 percent of the respondents are spending less than Rs. 2000, 29 percent of the respondents are spending Rs. 2001-4000, about 8 percent of the respondents are spending Rs. 4001-6000 and 2 percent of the respondents are spending Rs. 6001-8000 for maintaining the constructed toilet.

Table 15

Response of respondents regarding cleaning of toilet

\begin{tabular}{|l|l|l|}
\hline Response & Frequency & Percentage \\
\hline Daily & 51 & 57 \\
\hline Thrice a Week & 12 & 14 \\
\hline Twice a Week & 17 & 19 \\
\hline Once a Week & 8 & 9 \\
\hline Fortnightly & 1 & 1 \\
\hline Total & $\mathbf{8 9}$ & $\mathbf{1 0 0}$ \\
\hline
\end{tabular}

Source: Primary

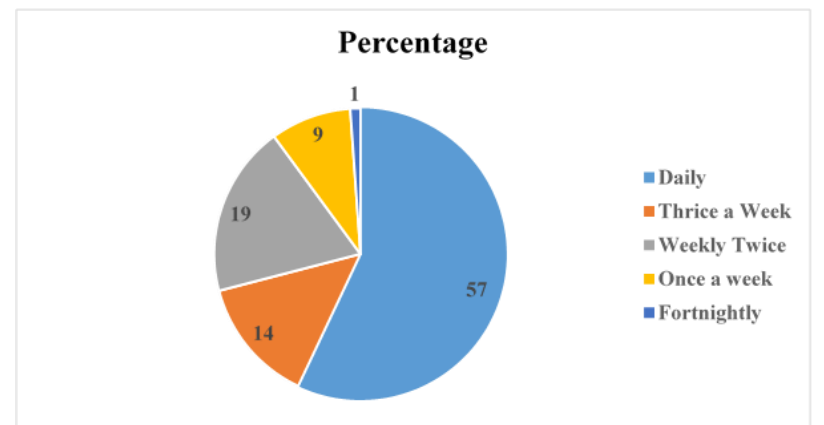

Fig. 10. Chart showing the response of respondents regarding cleaning of toilet

The table 15, shows how frequently the beneficiaries are cleaning the toilet which has been constructed for them. It was found that 57 percent of the respondents are cleaning their toilets everyday, about 14 percent of the respondents are cleaning their toilets thrice a week, about 19 percent of the respondents are cleaning their toilet twice a week, about 9 percent of the respondents are cleaning their toilet once a week and only about 1 per cent of the respondents are cleaning their toilet once in 15 days. 
Volume-3, Issue-11, November-2020

IJRESM https://www.ijresm.com | ISSN (Online): 2581-5792

Table 17

Rating of respondents on usage of the toilet

\begin{tabular}{|c|l|l|l|l|l|l|l|}
\hline S. No. & Parameters & \multicolumn{2}{|c|}{ Good } & \multicolumn{2}{c|}{ Acceptable } & \multicolumn{2}{c|}{ Poor } \\
\hline & & Frequency & Percentage & Frequency & Percentage & Frequency & Percentage \\
\hline 1 & Effective Operation & 80 & 90 & 8 & 9 & 1 & 1 \\
\hline 2 & Convenience & 83 & 93 & 6 & 7 & 0 & 0 \\
\hline 3 & Cleanliness & 79 & 89 & 10 & 11 & 0 & 0 \\
\hline 4 & Smell & 59 & 66 & 27 & 30 & 3 & 4 \\
\hline 5 & Ease of Repair & 58 & 65 & 27 & 30 & 4 & 5 \\
\hline
\end{tabular}

Source: Primary

Table 16

Response of respondents on effectiveness of training program

\begin{tabular}{|l|l|l|}
\hline Response & Frequency & Percentage \\
\hline Effective & 51 & 57 \\
\hline Not Effective & 0 & 0 \\
\hline Not aware & 34 & 38 \\
\hline Did not attend & 4 & 5 \\
\hline Total & $\mathbf{8 9}$ & $\mathbf{1 0 0}$ \\
\hline
\end{tabular}

Source: Primary

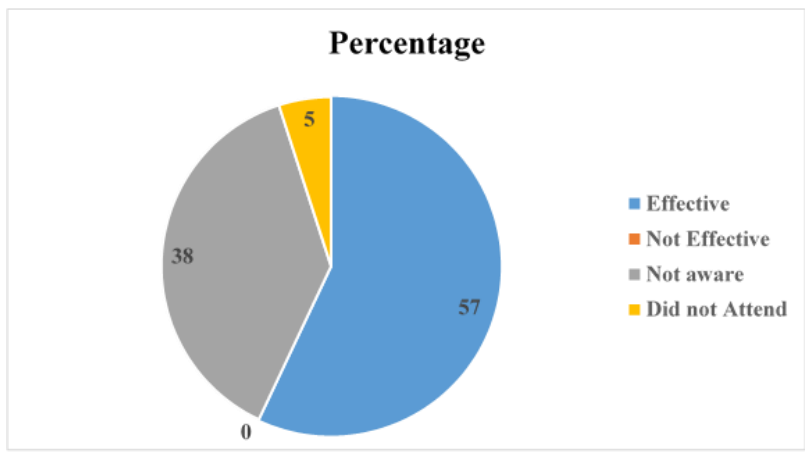

Fig. 11. Chart showing the response of respondents on effectiveness of training program

The table 16, shows the respondents response on effectiveness of the training program conducted by JK Tyres Ltd Mysuru and Taluk Panchayat on cleanliness and water management. Out of 89 respondents 57 percent of respondents have expressed that training program was very effective, about 5 percent of the respondents were aware of the training program but did not attend the training program, about 38 percent of the respondents were not aware of the training program.

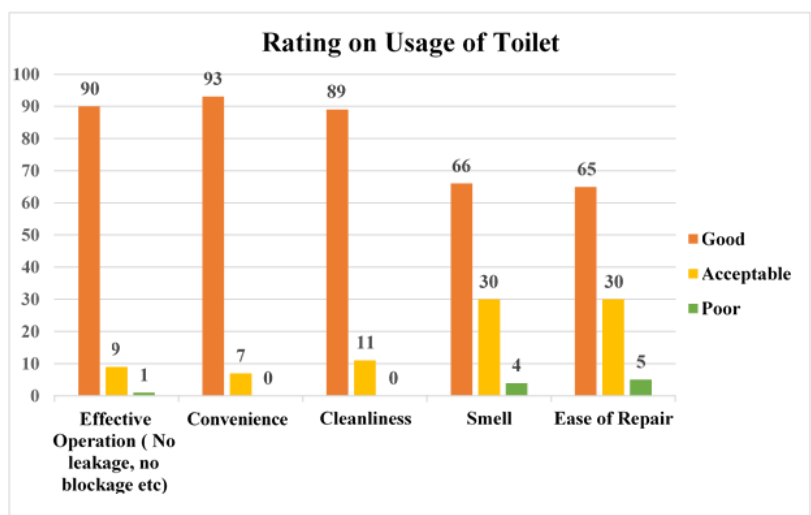

Fig. 12. Chart showing the rating of respondents on usage of toilet

The table 17, shows the rating of beneficiaries on the effective Usage of toilet. About 90 percent of the respondents have rated the effective operation as good, about 9 per cent of the respondents have rated the operation of toilet as average and about one percent of respondents have rated the operation of toilet as poor.

About 93 percent of respondents have responded that the convenience of toilet is good and about 7 percent of the respondents have expressed that it is acceptable.

On the cleanliness about 89 per cent of the respondents have responded that is it good and 11 percent of the respondents have expressed that it is acceptable.

About 66 percent of the respondents have responded good on the smell, about 30 per cent of the respondents have responded acceptable and about 4 percent of the respondents have responded poor.

On ease of repair 65 percent of the respondents have responded good, about 30 percent of the respondents have responded acceptable and about 5 percent of the respondents have responded poor.

\section{Conclusion}

This paper presented a study on manufacturing industry and corporate social responsibility on the society.

\section{References}

[1] S. B. Banjerjee, "Corporate Social Responsibility: The Good, the Bad and the Ugl." Edward Elgar Publishing Limited, Cheltenham, 2007.

[2] B. Chatterjee and N. Mitra, "CSR should contribute to the national agenda in emerging economies - the "Chatterjee Model," in International Journal of Corporate Social Responsibility, vol. 2, no. 1, 2017.

[3] C. A. Tilt, "Corporate Social Responsibility research: Importance of the context," in International Journal of Corporate Social Responsibility, vol. 1, no. 2, 2016.

[4] A. D. Gupta, "Corporate Social Responsibility: The Indian context (Crowther D, Jatana R, Representations of social responsibility ed., vol. 2, ICFAI, 2010.

[5] H. L. Johnson, "Can the Businessman Apply Christianity?," in Harvard Business Review, vol. 36, no. 4, pp. 68-76, 1958.

[6] P. Kaur, "The Effect of CSR on Consumer's Buying Behavior," in International Journal of Innovative Research and Development, vol. 2, no. $11,2013$.

[7] J. Moon, "Corporate Social Responsibility: A Very Short Introduction," Oxford University Press Inc., New York, 2014.

[8] R. Mullerat, "International Corporate Social Responsibility: The Role of Corporations in the Economic Order of the 21st Century," Kluwer Law I international, Alphen a den Rijn., 2010.

[9] N. Masoud, "How to win the battle of ideas in corporate social responsibility: The international pyramid model of CSR," in International Journal of Corporate Social Responsibility, vol. 2, no. 4, 2017.

[10] N. R Berad, "Corporate Social Responsibility - Issues and Challenges in India," in International Conference on Technology and Business Management, pp. 101, 2011. 
[11] P. Kseizak, "The benefits from CSR for a company and Society," in Journal of Corporate Responsibility and Leadership, vol. 3, no. 4, pp. 5365, 2016.

[12] B. Planken, "CSR across the globe: Dutch and Indian consumers' responses to CSR," in International Journal of Organizational Analysis, vol. 21, no. 3, pp. 357- 372, 2013.
[13] S. Kim and J. Bae, "Cross-cultural differences in concrete and abstract corporate social responsibility (CSR) campaigns: perceived message clarity and perceived CSR as mediators," in International Journal of Corporate Social Responsibility, vol. 1, no. 6, 2016. 